\title{
Identification of Corporate Value Through the Good Corporate Governance Mechanism
} (Banking in Indonesia 2015-2018)

\author{
Tatas Ridho Nugroho ${ }^{1 *}$, Rini Armin ${ }^{2}$,Marisha Khanida ${ }^{3}$ \\ 1,2,3 Faculty of Economics, Islamic University of Majapahit \\ ${ }^{*}$ Corresponding author Email: tatasridho14@gmail.com
}

\begin{abstract}
Developments in the financial sector in Indonesia, especially changes in the banking structure in Indonesia, are expected to provide positive changes for national finance. The existence of a corporate governance system can be an appropriate reference to be changed in a positive direction. Corporate governance that can be approved for increasing company value so that it attracts investors to invest. Corporate governance that is proxied by the board of directors, independent commissioners, managerial ownership, institutional ownership, audit board and audit quality on the value of the company proxied by Tobin's $Q$. The population of this study is the banking companies that were questioned on the Indonesia Stock Exchange in the 2015-2018 period. . The sample consisted of 17 companies selected by purposive sampling technique. Data analysis uses descriptive analysis and multiple linear regression. The results showed the partial board of directors (0.564), independent commissioners (0.487), managerial ownership ( 0.487$)$, audit board $(0.153)$ and audit quality $(0.780)$ were not significant to the firm's value $(>0.05)$ institutionally had a significant positive effect on the value company $(0.042<0.05)$. Simultaneously all of these variables do not oppose the value of the company with an F test value of $0.251>0.05$. Intended for companies to be more optimal in implementing GCG implementation not only discourse but actually implemented in order to get the company's long-term benefits.
\end{abstract}

Keywords: Good Corporate Governance Mechanism, Firm Value, Tobin's $Q$

\section{INTRODUCTION}

In the industrial era 4.0, more and more banking companies are operating, causing people to be more selective in choosing banks, as a result, competition in the banking world is getting tighter. The high level of competition will cause the high risk that will be faced by the bank so that it is necessary to have good bank management in order to maintain the bank's survival. From a monetary point of view, banks are companies that can help improve the country's economy. Supervision, reporting and company performance must be maintained in order to increase company value so that it can help stabilize the country's economy. There are still many banking companies that have not implemented proper supervision so that it can trigger fraud in a company, reporting that is not timely and even some do not report their financial statements in certain years. This can be overcome by implementing good corporate governance mechanisms. A company can run well, one of which is due to the investment of shareholders who entrust their shares to the company, so the company must be able to improve the welfare of its investors through improving company performance.

One way to measure the level of prosperity of shareholders is through company value. "A high increase in company value is a long-term goal that should be achieved by a company, this is reflected in the market price of its shares because investors' assessment of the company can be observed through the movement of the company's stock prices that are transacted on the stock exchange. The higher the value of a company, the higher the prosperity of investors [1]. The concept of corporate governance is proposed in order to achieve a more transparent company management for stakeholders. The corporate governance system provides effective protection for stockholders and stakeholders so that they will be sure of getting a return on their investment [2]. Practices of corporate governance have been studied as a solution for agency conflicts that appear when a separation exists between the owner and manager roles." According to agency 
theory, ownership concentration acts as an internal mechanism to alleviate owner-manager conflict [3].

Conflicts of interest between managers and shareholders (company owners) which are often called agency problems will arise in the process of maximizing firm value. "It is not uncommon for company management to have other goals that may conflict with the company's main goals. It is this difference of interest that causes a conflict which is commonly referred to as an agency conflict. This difference occurs because managers prioritize personal interests, on the other hand shareholders dislike the personal interests of managers because what the manager does will increase costs for the company, causing a decrease in company profits and dividends to be received by shareholders, which in turn has an impact on the decline in company value. The implementation of the Good Corporate Governance system can be the right solution in minimizing these conflicts of interest so as to provide effective protection to shareholders and creditors to recover their investment rights fairly, precisely and efficiently as possible, and ensuring that management acts as best as possible to increase value company."

The management of companies by public companies in Indonesia is still weak. This is indicated by the weakness of accounting and regulatory standards, accountability to shareholders, standards of disclosure and transparency, and corporate management processes. This fact indirectly shows the weakness of public companies in Indonesia in carrying out good management and in satisfying company stakeholders. Business players in Indonesia have agreed to implement good corporate governance (GCG) in an effort to overcome these weaknesses. This is in accordance with the signing of the Letter of Intent (LOI) agreement with the IMF in 1998, which includes a schedule for improving the management of companies in Indonesia [1].

Basically, the relationship between Bank Indonesia and Commercial Banks is a form of relationship between the principal and the agent that cannot be avoided from conflicts or differences of interest. This difference arises when there are differences in objectives between Bank Indonesia (principal) and Commercial Banks (agent) and because of the difficulty of Bank Indonesia in knowing the truth of banking financial reporting [4].
The definition of the concept of Good Corporate Governance according to IICG (The Indonesian Institute for Corporate Governance) is a series of mechanisms to direct and control a company so that the company's operations run in accordance with the expectations of stakeholders. The importance of Good Corporate Governance is emphasized even more after the bankruptcy of large companies, accounting scandals, and economic crises in various countries. The implementation of the Good Corporate Governance Mechanism is expected to be able to overcome the problems that have been faced by public companies in Indonesia, including banking companies, so as to increase the value of a company. The mechanism of Good Corporate Governance in this study is proxied in six variables, namely the board of directors, independent commissioners, managerial ownership, institutional ownership, audit committee and audit quality.

The Board of Directors is a corporate organ representing shareholders who are authorized and responsible for managing the company. The Board of Directors plays a role in determining policies and strategies to be used, both short-term and long-term policies and ensuring the achievement of the stated goals. The Board of Directors must ensure that management acts in accordance with what the members of the board want [5]. The relationship between the Board of Directors and the banking sector is very important, considering that the relationship between the bank and foreign investors is a reference in the activities of collecting and channeling public funds. The better the management of the company by the board of directors, the more confidence level of shareholders to invest their shares so that the company value will increase. Based on this explanation, the hypothesis of this study is:

H1: The Board of Directors has a positive influence on Company Value.

Independent Commissioners based on the National Committee on Governance (KNKG) are members of the board of commissioners who are not affiliated with management, other members of the board of commissioners and controlling shareholders, free from business relationships or other relationships that may affect their ability to act independently or act solely for their interests. company. The responsibility of an independent commissioner is to oversee all decisions made by the board of directors in managing the company in accordance with the principles of good corporate 
governance. Independent commissioners will have a good impact on the company so that the company's value increases and will attract investors to be willing to pay more. This is in line with research [2] which results show that independent commissioners have a positive effect on firm value. Based on this explanation, the hypothesis of this study is:

$\mathrm{H} 2$ : The Independent Commissioner has a positive influence on Company Value.

Managerial ownership is company shares owned by company management. Ownership of shares can reduce agency risks arising from the interests of various parties, be it the principal or the agent. Management who owns shares in the company will feel the impact directly in the form of risks on their decision making so that they will be more careful in doing so so that their actions can improve financial performance and have a good impact on company value. The greater the managerial share ownership in a company, the more active management tends to be for the interests of shareholders because if there is a wrong decision, management will also bear the consequences [6]. The results of the study [7] prove that managerial ownership has a positive effect on firm value, so the hypothesis of this study is:

H3: Managerial Ownership has a positive influence on Firm Value. Institutional ownership is ownership of shares by the government, financial institutions, legal entities, foreign institutions, trusts and other institutions.

Institutional ownership has a very important role in minimizing agency conflicts that occur between managers and shareholders. Institutional ownership acts as a controlling party for company managers so that it can minimize fraud by company management [8]. As a monitoring agent that will certainly ensure the prosperity of investors, the influence of institutional ownership is suppressed through their sizable investment in the capital market. Supervision carried out by the institution will create good management performance, thereby increasing company value. This is supported by research results [6] which prove that institutional ownership has a positive effect on firm value, so the hypothesis is:

H4: Institutional Ownership has a positive influence on Firm Value

The Audit Committee based on the 2006 National Committee on Governance Policy is a group of people who are selected by a larger group to do certain jobs or to perform special tasks or a number of members of the board of commissioners of a client company who are responsible for assisting auditors in maintaining their independence from management. The audit committee has a duty to observe the internal control system, supervise external audits and supervise financial reports to reduce the opportunistic nature of management [7]. The supervision carried out by the audit committee can minimize fraud caused by management and can improve management performance in order to increase company value. Based on this description, the hypothesis is:

H5: The Audit Committee has a positive influence on Firm Value. Audit quality of public accountants is one of the foremost steps in building a healthy, clean, and responsible business life in a country because public accountants are parties who have the ability, expertise and opportunity to detect various fraudulent activities carried out by companies.

The proxy of Audit Quality is the Auditor's Reputation, the auditor's reputation is obtained based on the trust of the audit service user, the better the auditor's performance will increase the trust of the service users so that their reputation will also increase [9]. Selection of a large public accounting firm can be the right solution to increase the value of a company because a reputable public accountant will generate a high level of trust by investors. So that the hypothesis of the explanation is:

H6: Audit quality has a positive influence on Firm Value.

The board of directors, independent commissioners, managerial ownership, institutional ownership, audit committee and audit quality are all part of the good corporate governance mechanism which can both increase firm value. The board of directors as the manager of company policy and strategy, assisted by the audit committee as a financial supervisor, will work together to improve company performance in order to increase company value. In addition, independent commissioners and institutional ownership are responsible for monitoring the performance of company management so that there will be no opportunistic behavior in a manager, this will trigger an increase in company value, balanced with managerial ownership which also contributes to share ownership. Then the manager will continue to be motivated to increase company profits and support the quality of audits by using Big 4 KAP which will further increase the level of investor confidence in investing so that the company's stock price will rise and this can increase company value. Big KAP is synonymous with high reputable KAP. The size of 
KAP also shows the ability of auditors to be independent and to carry out audits in a professional manner, because KAP becomes less economically dependent on clients. The client is also less able to influence the auditor's opinion [10]. Based on this explanation, conclusions can be drawn about the hypothesis, namely: H7: Simultaneously (jointly) there is influence of the Board of Directors, Independent Commissioners, Managerial Ownership, Institutional Ownership, Audit Committee and Audit Quality on Company Value.

Based on the description above, the purpose of this study is to examine whether the value of banking companies is influenced by the good corporate governance mechanism in banking companies listed on the Indonesian Stock Exchange (IDX) for the 2015-2018 period.

\section{LITERATURE REVIEW}

\subsection{Agency Theory}

Agency Theory is a concept that describes the contractual relationship between principals and agents. In this case the principal is the owner or shareholder, while what is meant by agent is the management who manages the company. Agency theory emphasizes the importance of separating the interests of the principal and agent by submitting the management of the company from the principals to the agents. The purpose of separating management from company ownership is for the principal to obtain the maximum possible profit at the most efficient cost possible when the company is managed by an agent. This theory is the basis for understanding good corporate governance. The concept of good corporate governance is related to how owners (shareholders) believe that managers will provide benefits for them and will not commit fraud that will harm shareholders [5]

Signaling Theory

Signaling Theory is an action taken by company management which provides guidance to investors about how management views the company's prospects. The information released by the company is important because it affects the investment decisions of parties outside the company, namely investors and business people [6]. Signal theory states that investors can get various information about companies that can manage their companies well through the implementation of good corporate governance so that they can increase company value. This can be used as a reference for investors in determining their decisions.

\subsection{Good Corporate Governance}

Good Corporate Governance, according to the Circular of the State Minister for Capital Markets and BUMN Supervisory No.S.106 / MPMPBUMN / 2000 , is all matters relating to effective decision making originating from corporate culture, ethics, values, systems, business processes, policies and the company's organizational structure which aims to encourage and support company development, more efficient and effective management of resources and risks, as well as corporate accountability to shareholders and other stakeholders. The research focuses on the mechanism of Good Corporate Governance which is proxied in six variables, namely the board of directors, independent commissioners, managerial ownership, institutional ownership, audit committee and audit quality.

\subsection{Company Value}

Firm Value is a description of the equity of a company, the higher the equity of a company, the higher the value of the company. This can be seen from how much investors fund a company so that it can increase the company's share price in the stock market. High company value is the desire of investors, because high company value indicates high investor prosperity. The wealth of investors and companies is reflected in the stock market price which is also a reflection of funding decisions and asset management [8].

\section{RESEARCH METHOD}

This research is a quantitative study because the data used in this study are related to numbers and statistical analysis which are then tested using the SPSS Statistics program. Sources of data used in this study are secondary data in the form of historical annual reports in archives or documents obtained by researchers indirectly from banking companies on the Indonesia Stock Exchange through the official website, namely the website www.idx.co.id and the official websites of each. each bank. This research was conducted from February to March 2019, with the object of research, namely banking companies listed on the Indonesia Stock Exchange (BEI) for the 2015-2018 period. The instrument in this research is documentation in the form of documents which will later be processed into research data. The data collection method uses the documentation method by collecting data on the annual reports of banking companies that have been published on the Indonesia Stock Exchange for the 2015-2018 period and then 
processed using purposive sampling technique to obtain a research sample.

The independent variable in this study is the good corporate governance mechanism which is proxied by six variables, namely the board of directors, independent commissioners, managerial ownership, institutional ownership, audit committee and audit quality, while the dependent variable is firm value.

The board of directors is a representative of a series of shareholders who must be able to ensure that the company's goals can be carried out well because they have the responsibility to determine policies and strategies for the implementation of good company management [11]. The board of directors in this study can be measured by a dummy variable, namely giving a value of 0 if there are less than 3 members of the board of directors and a score of 1 if the members consist of 3 or more people. This is in accordance with Bank Indonesia Regulation Number 8/4 / PBI / 2006 concerning the Implementation of Good Corporate Governance which states that the number of members of the board of directors is at least 3 (three) persons.

Independent commissioners are members of the board of commissioners who do not have any business relationship with the company so that it can influence their independence actions, independent commissioners are usually members of the board from outside the company. Independent commissioners are measured by the ratio or formula as follows:

KIND $=\frac{\sum \text { KIND dari luar }}{\sum \text { anggota dewan komisaris }} \times 100 \%$

Notes :

KIND = Independent Commissioner

Managerial ownership is the level of share ownership embedded in the company by the board of directors, managers, commissioners and other parties involved with company management. The following is the managerial ownership measurement formula:

Notes :

$$
\mathrm{KPMJ}=\frac{\sum \text { saham manajemen }}{\sum \text { saham beredar }} \times 100 \%
$$

KPMJ = Managerial ownership

Institutional ownership is the ownership of shares owned by both local and foreign institutional investors, which include banks, pension funds, insurance companies, limited liability companies, and other financial institutions. The following is the institutional ownership measurement formula:

$$
\text { KPINS }=\frac{\sum \text { saham institusi }}{\sum \text { saham beredar }} \times 100 \%
$$

Notes :

KPINS = Institutional Ownership

The audit committee is one of the good corporate governance mechanisms that can affect bank financial performance [9]. The Audit Committee is a committee formed by the board of commissioners to help carry out the duties and functions of the board of commissioners related to the financial reporting process. Bapepam Circular Letter No. SE-03 / PM / 2000 states that the audit committee in Indonesian public companies consists of at least three members and is chaired by the company's independent commissioner with two independent external parties. The calculation of the audit committee is as follows:

$$
\text { KMAU }=\frac{\sum \text { komite audit independen }}{\sum \begin{array}{c}
\text { anggota komite audit } \\
\times 100 \%
\end{array}}
$$

Notes :

KMAU = Audit Commite

The audit committee is one of the good corporate governance mechanisms that can affect bank financial performance [9]. The Audit Committee is a committee formed by the board of commissioners to help carry out the duties and functions of the board of commissioners related to the financial reporting process. Bapepam Circular Letter No. SE-03 / PM / 2000 states that the audit committee in Indonesian public companies consists of at least three members and is chaired by the company's independent commissioner with two independent external parties. The calculation of the audit committee is as follows:

a) Price Waterhouse Coopers $(\mathrm{PwC})$, in Indonesia PwC is affiliated with KAP Tanudiredja, Wibisana \& Partners.

b) Deloitte Touche Tohmatsu, represented in Indonesia by KAP Osman Bing Satrio and Eny (Deloitte member auditors).

c) Ernst and Young (EY), in Indonesia EY is affiliated with KAP Purwantono, Suherman \& Surja (PSS).

d) Klynveld Peat Marwick Goeldener (KPMG), in Indonesia KPMG has a local partner, namely KAP Sidharta \& Widjaja led by Tohana Widjaja.

Firm value is market value. If the company's stock price rises, the company's value will increase. The higher the share price, the higher the prosperity of the shareholders [7]. A good reflection of company value can be seen from how the company's ability to show profits and manage its company's assets properly so that it will trigger investor interest and level of confidence in funding a company. This can have an impact on the increase in the company's 
share price in the stock market. Firm value can be measured using Tobin's $Q$ ratio because this ratio can show the current financial market estimate of how much the return on each investment has been invested in a company. This can have a positive impact on the company's future growth and development through its investment policies. Here's the formula from Tobin's Q:

$$
\text { Tobin's } Q=\frac{(E M V+D e b t)}{T \cdot A}
$$

Notes :

Tobin's Q (\%) = Company Value

EMV = Equity Market Value (EMV = closing price (closing price of shares at the end of the financial year) $\mathrm{x}$ number of ordinary shares outstanding)

Debt $\quad=$ Total Liability Value

T.A $\quad=$ Total Asset Value

Descriptive statistical analysis used by researchers to describe the variable data under study. Furthermore, classical assumption testing is carried out to fulfill the requirements for hypothesis testing so that there is no bias in the data under study. The classical assumption test is done by testing data normality, autocorrelation, multicollinearity and heteroscedasticity. Multiple linear regression analysis model is used to investigate independent variables with more than one variable with the following regression equation:

$$
\begin{gathered}
\mathrm{Y}=\alpha+\beta 1 \mathrm{X1}+\beta 2 \mathrm{X} 2+\beta 3 \mathrm{X3}+\beta 4 \mathrm{X4} \\
+\beta 5 \mathrm{X5}+\beta 6 \mathrm{X6}+\varepsilon
\end{gathered}
$$

Notes :

$\mathrm{Y} \quad=$ Company Value

$\alpha \quad=$ Konstanta

$\beta 1-\beta 6=$ Koefisien Regresion

$\mathrm{X} 1=$ Board of Directors

$\mathrm{X} 2=$ Independent Commissioner

X3 = Managerial Ownership

X4 = Institutional Ownership

$\mathrm{X} 5=$ Audit Committee

X6 $=$ Audit Quality $\varepsilon=$ Component error in the model

Hypothesis testing is done by means of the $t$ test to analyze the effect of each independent variable partially (individually) on the dependent variable, then the $\mathrm{F}$ test is carried out to analyze the effect simultaneously (together) of the independent variable on the dependent variable. The $\mathrm{R} 2$ test is the final test to determine how much the percentage of influence of the independent variable on the GCG mechanism on the dependent variable of firm value.

\begin{tabular}{|c|c|c|c|c|c|}
\hline & $\mathrm{N}$ & $\begin{array}{l}\text { Minim } \\
\text { um }\end{array}$ & $\begin{array}{l}\text { Maxim } \\
\text { um }\end{array}$ & $\begin{array}{c}\text { Mea } \\
\mathrm{n}\end{array}$ & $\begin{array}{c}\text { Std. } \\
\text { Deviati } \\
\text { on }\end{array}$ \\
\hline $\begin{array}{l}\text { Board of } \\
\text { Director }\end{array}$ & $\begin{array}{l}6 \\
8\end{array}$ & ,00 & 1,00 & $\begin{array}{r}970 \\
6\end{array}$ & , 17021 \\
\hline $\begin{array}{l}\text { Independen } \\
\mathrm{t} \\
\text { Commissio } \\
\text { ner }\end{array}$ & $\begin{array}{l}6 \\
8\end{array}$ & ,33 &, 75 & $\begin{array}{r}, 581 \\
2\end{array}$ & ,09447 \\
\hline $\begin{array}{l}\text { Managerial } \\
\text { ownership }\end{array}$ & $\begin{array}{l}6 \\
8\end{array}$ & ,00 & ,72 & $\begin{array}{r}, 053 \\
1\end{array}$ & 16999, \\
\hline $\begin{array}{l}\text { Institutiona } \\
1 \text { ownership }\end{array}$ & $\begin{array}{l}6 \\
8\end{array}$ & ,01 & ,96 & $\begin{array}{r}553 \\
8\end{array}$ & ,28351 \\
\hline $\begin{array}{l}\text { Audit } \\
\text { Committee }\end{array}$ & $\begin{array}{l}6 \\
8\end{array}$ & ,33 & ,67 & $\begin{array}{r}575 \\
3\end{array}$ & 11107, \\
\hline $\begin{array}{l}\text { Audit } \\
\text { Quality }\end{array}$ & $\begin{array}{l}6 \\
8\end{array}$ & ,00 & 1,00 & $\begin{array}{r}764 \\
7\end{array}$ & ,42734 \\
\hline $\begin{array}{l}\text { The value } \\
\text { of the } \\
\text { company }\end{array}$ & $\begin{array}{l}6 \\
8\end{array}$ & ,92 & 2,41 & $\begin{array}{r}1,11 \\
82\end{array}$ & 23485, \\
\hline $\begin{array}{l}\text { Valid N } \\
\text { (listwise) }\end{array}$ & $\begin{array}{l}6 \\
8\end{array}$ & & & & \\
\hline
\end{tabular}

\section{RESULTS AND DISCUSSION}

Table 1: Descriptive Statistics

Table 1 Descriptive Statistics describes the characteristics of the data on each research variable. The board of directors as measured by the dummy variable has an average value (mean) of 0.9706 with a standard deviation of 0.17021 . Independent commissioners have a minimum value of 0.33 and a maximum value of 0.75 , while the mean value is 0.5812 with a standard deviation of 0.09447 . Managerial ownership has a minimum value of 0.00 and a maximum value of 0.72 , while the mean value is 0.0531 with a standard deviation of 0.16999 . Institutional ownership has a minimum value of 0.01 and a maximum value of 0.96 , while the mean value is 0.5538 with a standard deviation of 0.28351 . The audit committee has a minimum value of 0.33 and a maximum value of 0.67 , while the mean value of the audit committee is 0.5753 with a standard deviation of 0.11107 . Audit quality measured using dummy variables has a mean value of 0.7647 with a standard deviation of 0.42734 . The firm value through Tobin's $\mathrm{Q}$ has a minimum value of 0.92 and a maximum value of 2.41 , while the mean value is 1.1182 with a standard deviation of 0.23485 . 
1. Classic assumption test

\section{Normality Test}

Table 2: Normality Test Result Kolmogorov-Smirnov (K-S)

One-Sample Kolmogorov-Smirnov Test

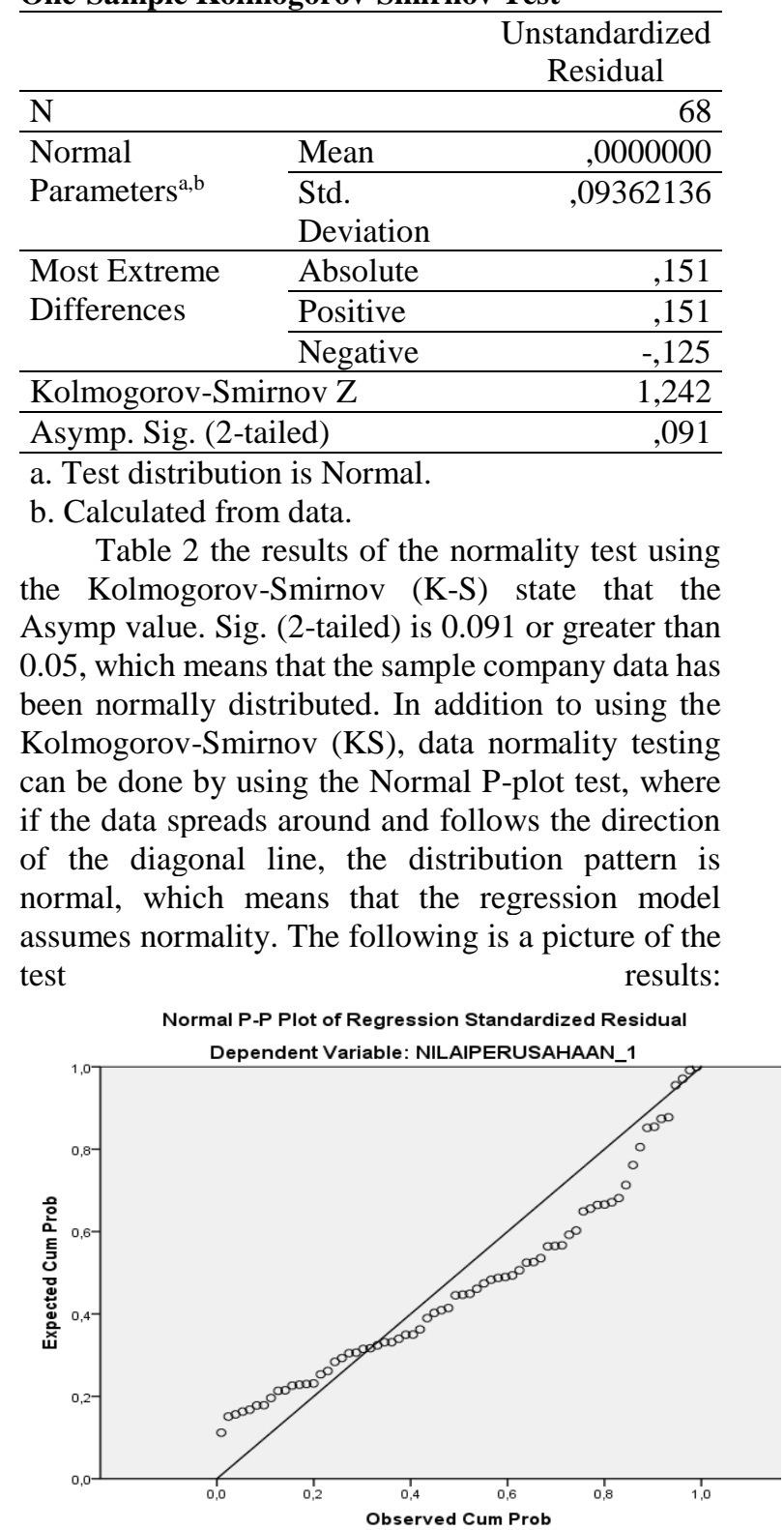

Figure 1: Normal P-Plot Test
2. Autokorelasi Test

Table 3: Autocorrelation Durbin-Watson Test Result

\begin{tabular}{lccc}
\multicolumn{4}{c}{ Model Summary $^{\mathbf{b}}$} \\
\hline Model & R & $\begin{array}{c}\text { Std. Error of the } \\
\text { Estimate }\end{array}$ & $\begin{array}{l}\text { Durbin- } \\
\text { Watson }\end{array}$ \\
\hline 1 &, $342^{\text {a }}$ &, 09812 & 1,167 \\
\hline a. Predictors: (Constant), KUALITASAUDIT_1, \\
DEWANDIREKSI_1, \\
KOMISARISINDEPENDEN_1, \\
KEPEMILIKANINSTITUSIONAL_1, \\
KOMITEAUDIT_1, \\
KEPEMILIKANMANAJERIAL_1 \\
b. Dependent Variable: NILAIPERUSAHAAN_1
\end{tabular}

Table 3, the results of the autocorrelation test using Durbin-Watson stated that $0<1.167<1.4217$, which means that the D-W value of 1.167 is smaller than the $\mathrm{dL}$ value of 1.4217 . So it can be concluded that there is no positive autocorrelation in the regression model of this study.

3. Multikolinieritas Test

Table 4: Multikolinieritas Test Result

\section{Coefficients $^{\mathrm{a}}$}

\begin{tabular}{|c|c|}
\hline \multirow[b]{2}{*}{ Model } & $\begin{array}{c}\text { Collinearity } \\
\text { Statistics }\end{array}$ \\
\hline & $\begin{array}{c}\text { Toleran } \\
\text { ce }\end{array}$ \\
\hline \multicolumn{2}{|l|}{1 (Constant) } \\
\hline DEWANDIREKSI_1 & $\begin{array}{rr}, 892 & 1,12 \\
1\end{array}$ \\
\hline KOMISARISINDEPENDEN_1 & $\begin{array}{rr}, 879 & 1,13 \\
7\end{array}$ \\
\hline $\begin{array}{l}\text { KEPEMILIKANMANAJERIA } \\
\text { L_1 }\end{array}$ & $\begin{array}{rr}, 575 & 1,74 \\
& 0\end{array}$ \\
\hline $\begin{array}{l}\text { KEPEMILIKANINSTITUSIO } \\
\text { NAL_1 }\end{array}$ & $\begin{array}{r}, 814 \\
\end{array}$ \\
\hline KOMITEAUDIT_1 & $\begin{array}{rr}, 783 & 1,27 \\
& 7\end{array}$ \\
\hline KUALITASAUDIT_1 & $\begin{array}{rr}, 584 & 1,71 \\
& 3\end{array}$ \\
\hline \multicolumn{2}{|c|}{ a. Dependent Variable: NILAIPERUSAHAAN_1 } \\
\hline $\begin{array}{l}\text { Table } 4 \text { of the multicollinearity } \\
\text { hat the tolerance value of all inde } \\
\text { anges from } 0.575 \text { to } 0.892 \text {, which } \\
\text { greater than } 0.01 \text { and the VIF va } \\
1.121 \text { to } 1.740 \text { which means that it } \\
10.00 \text {. Thus, it can be con }\end{array}$ & $\begin{array}{l}\text { t results states } \\
\text { dent variables } \\
\text { eans that it is } \\
\text { ranges from } \\
\text { ot greater than }\end{array}$ \\
\hline
\end{tabular}


independent variables do not have multicollinearity problem

4. Heteroskedastisitas Test

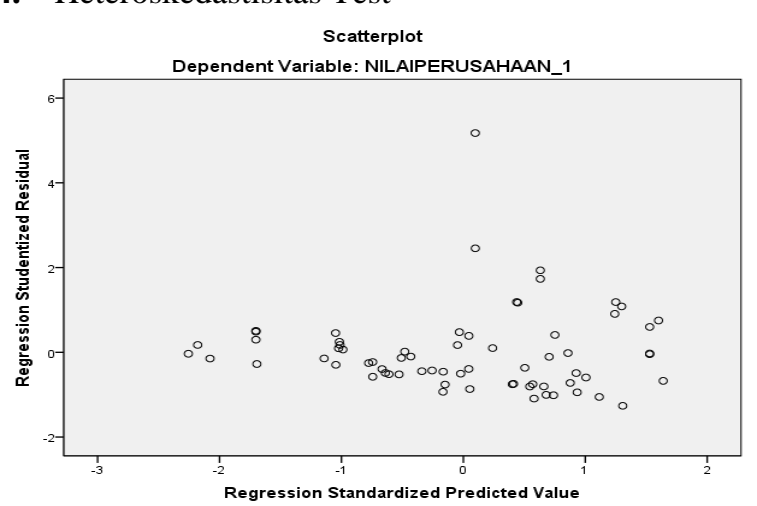

Figure 2: Heteroskedastisitas Test Result

Figure 2 The results of the heteroscedasticity test show that the data (dots) spread above and below the number 0 on the $\mathrm{Y}$ axis randomly and do not form a certain pattern so that it can be concluded that the data in this regression test occurs homoscedasticity or there is no heteroscedasticity problem.
Table 5: Multiple Linear Regression and Partial Test (T test)

\section{Coefficients $^{\mathrm{a}}$}

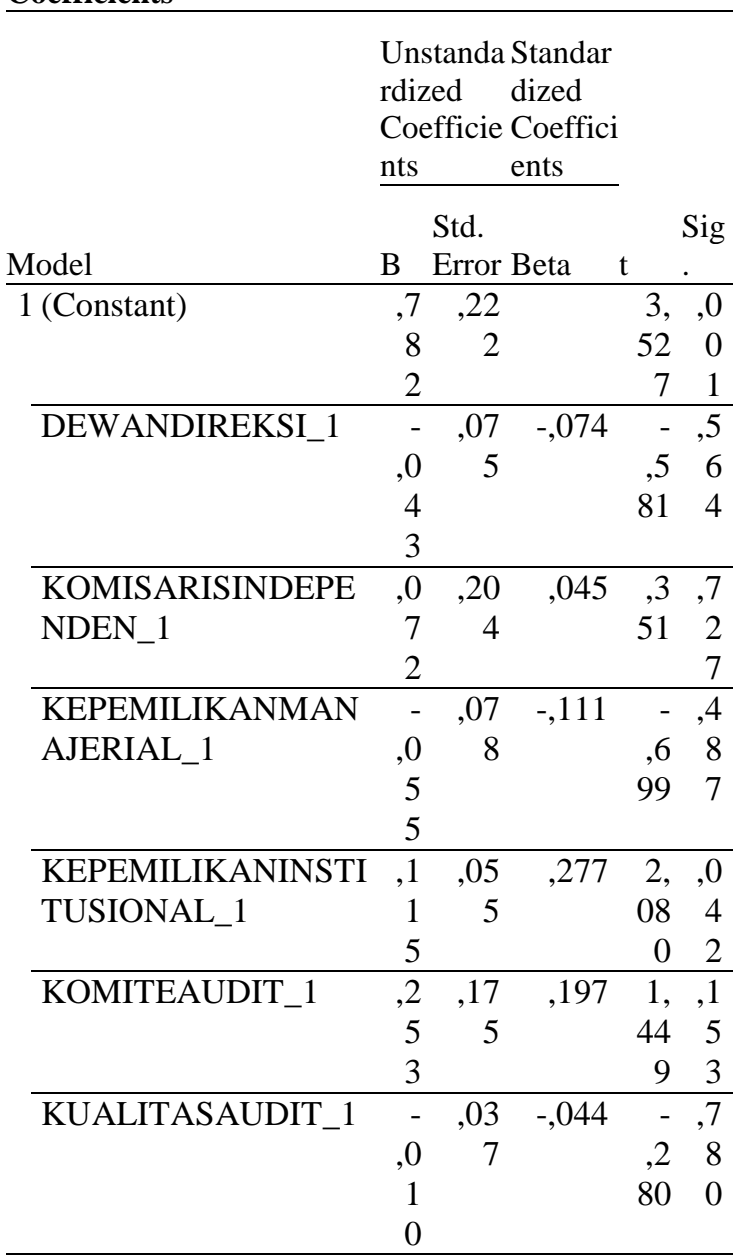

a. Dependent Variable: NILAIPERUSAHAAN_1

\section{Linear Regression Analysis}

Based on Table 5 which shows the results of calculations using the SPSS program, the following regression results are obtained:

$$
\begin{aligned}
\mathrm{Y}=0,782-0, & 043 \times 1 \\
& +0,072 \times 2-0,055 \times 3 \\
& +0,115 X 4 \\
& +0,253 \times 5-0,010 \times 6+\varepsilon
\end{aligned}
$$

\section{Hipotesis Test}

1. Partial (t) Test

Based on Table 5 partial test results ( $\mathrm{t}$ test), the interpretation is as follows:

A. The Board of Directors has a t-test value of -0.581 $\leq \mathrm{t}$ table (1.9996) with a significance of $0.564>0.05$ $(\alpha)$ then $\mathrm{H} 0$ is accepted and $\mathrm{Ha}$ is rejected. So it can 
be concluded that the 1st hypothesis in this study is rejected with the explanation that the board of directors has no positive effect on firm value.

B. The Independent Commissioner has a t-test value of $0.351 \leq t$ table (1.9996) with a significance of $0.727>0.05(\alpha)$, so H0 is accepted and Ha is rejected. So it can be concluded that the second hypothesis in this study is rejected with the explanation that independent commissioners have no positive effect on firm value.

C. Managerial ownership has a t-test value of -0.699 $\leq \mathrm{t}$ table (1.9996) with a significance of $0.487>0.05$ $(\alpha)$, so H0 is accepted and Ha is rejected. So it can be concluded that the third hypothesis in this study is rejected with the explanation that managerial ownership has no positive effect on firm value.

D. Institutional ownership has a t-test value of $2.080>t$ table (1.9996) with a significance of 0.042 $<0.05(\alpha)$, so H0 is rejected and Ha is accepted. So it can be concluded that the fourth hypothesis in this study is accepted with the explanation that institutional ownership has a positive effect on firm value.

E. The Audit Committee has a t-test value of 1.449 $\leq \mathrm{t}$ table (1.9996) with a significance of $0.153>0.05$ $(\alpha)$, so $\mathrm{H} 0$ is accepted and $\mathrm{Ha}$ is rejected. So it can be concluded that the fifth hypothesis in this study is rejected with the explanation that the audit committee has no positive effect on firm value.

F. Audit quality has a t-test value of $-0.280 \leq \mathrm{t}$ table (1.9996) with a significance of $0.780>0.05(\alpha)$, so $\mathrm{HO}$ is accepted and $\mathrm{Ha}$ is rejected. So it can be concluded that the 6th hypothesis in this study is rejected with the explanation that audit quality has no positive effect on firm value.

\section{The Simultaneous Significance Test}

Table 6: Signifikansi Simultan Test Result (Test F)

ANOVA $^{b}$

\begin{tabular}{|c|c|c|c|c|c|}
\hline Model & $\begin{array}{c}\text { Sum of } \\
\text { Squares }\end{array}$ & $\mathrm{df}$ & $\begin{array}{l}\text { Mean } \\
\text { Square }\end{array}$ & $\mathrm{F}$ & Sig. \\
\hline 1 Regression & ,078 & 6 & ,013 & 1,347 &, $251^{\mathrm{a}}$ \\
\hline Residual & ,587 & 61 & , 010 & & \\
\hline Total & ,665 & 6 & & & \\
\hline
\end{tabular}

a. Predictors: (Constant), KUALITASAUDIT_1, DEWANDIREKSI_1,

KOMISARISINDEPENDEN_1, KEPEMILIKANINSTITUSIONAL_1, KOMITEAUDIT_1, KEPEMILIKANMANAJERIAL_1

b. Dependent Variable: NILAIPERUSAHAAN_1 Based on Table 6, the simultaneous significance test results ( $\mathrm{F}$ test), the $\mathrm{F}$ test value is
$1.347<\mathrm{F}$ table (2.2514) with a significance of $0.251>0.05(\alpha)$, then $\mathrm{H} 0$ is accepted and $\mathrm{Ha}$ is rejected. So it can be concluded that the 7 th hypothesis in this study is rejected with the explanation that the independent variables, namely the board of directors, independent commissioners, managerial ownership, institutional ownership, audit committee, and audit quality do not have a simultaneous (joint) significant effect on firm value.

3. Coefficient of Determination Test $\left(\mathrm{R}^{2}\right)$

Table 7: Koefisien Determinasi Test Result (R2)

Model Summary ${ }^{\mathrm{b}}$

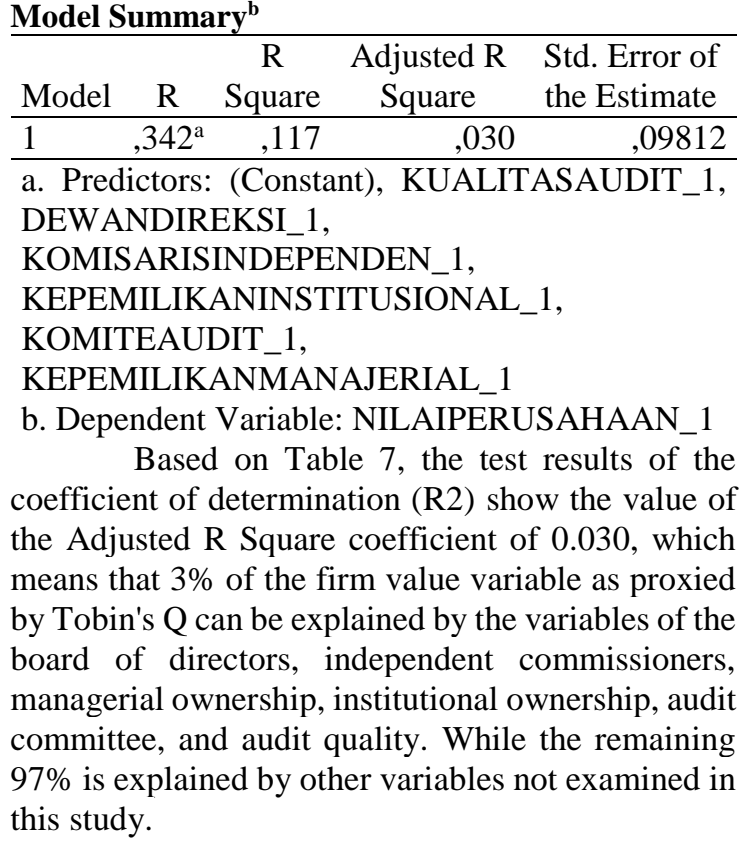

\section{DISCUSSION}

\subsection{The Effect of the Board of Directors on Company Value}

The independent variable, namely the good corporate governance mechanism, which is proxied by the Board of Directors, has no effect on Firm Value. The results of this study are in accordance with research conducted by Pramurza and Haryadi (2016) which states that the number of Directors has no significant effect on Company Value. The results of this study state that the board of directors in the company cannot guarantee the presence or absence of the level of fraud in the management of the company so that the board of directors cannot affect the increase or decrease in company value. 


\subsection{The Effect of Independent Commissioners on Company Value}

The independent variable, namely the good corporate governance mechanism, which is proxied by an Independent Commissioner, has no effect on Firm Value. The results of this study are in accordance with research conducted by Gosal, et al. (2018) which states that the Independent Commissioner has no significant effect on Company Value. The results of this study indicate that the existence of an independent commissioner in a company does not guarantee that the company can avoid the problem of fraud caused by various interests of management and other parties. This study found that some independent commissioners are still affiliated with the company, while the requirements to become independent commissioners are outsiders who do not have an affiliation with the company selected through an official meeting. So that independent commissioners cannot influence the increase or decrease in firm value.

\subsection{The Effect of Managerial Ownership on}

Firm Value The independent variable, namely the good corporate governance mechanism, which is proxied by Managerial Ownership, has no effect on Firm Value.

The results of this study are consistent with research conducted by Gosal, et al. (2018) who found that Managerial Ownership has no effect on Firm Value. The results of this study indicate that there are few companies whose shares are owned by management, because many companies realize that managerial ownership does not guarantee that they can increase firm value. In fact, managerial ownership will actually decrease the value of the company, because the more shares owned by the management will trigger an opportunistic attitude in which the company management is more concerned with personal interests than the interests of the company by performing income smoothing which makes the company look good financially.

\subsection{The Effect of Institutional Ownership on Firm Value The independent variable, namely the good corporate governance mechanism, which is proxied by Institutional Ownership, has a positive effect on Firm Value.}

The results of this study are in accordance with research conducted by Gosal, et al (2018) which states that Institutional Ownership has an effect on Firm Value. This is in accordance with the results of this study which have a significant positive value, meaning that if Institutional Ownership increases, the firm value also increases. Institutional ownership has an important role in overseeing the management process of the company, namely by pressing the management to further improve its performance in accordance with good corporate governance so that it can increase the growth of company value which in turn can benefit shareholders through increasing share prices and company profits.

\subsection{The Effect of the Audit Committee on Firm} Value The independent variable, namely the good corporate governance mechanism, which is proxied by the Audit Committee, has no effect on Firm Value.

The results of this study are consistent with research conducted by Marini \& Marina (2017) which states that the Audit Committee has no effect on Firm Value. The existence of an audit committee does not guarantee that the company's performance will increase so that it can increase the growth of company value. It is clear that the audit committee has the responsibility to oversee the financial reporting process as well as in the disclosure of these financial statements, but this does not guarantee that the audit committee can be independent in its duties, especially if the audit committee is not an independent party from outside the company but a party from within. companies so that they can trigger fraud in the financial reporting process. It can be concluded that the existence of an audit committee does not affect the growth or increase in company value.

5.6. The Effect of Audit Quality on Firm Value The independent variable, namely the good corporate governance mechanism, which is proxied by Audit Quality, has no effect on Firm Value.

The results of this study are in accordance with the research conducted by Pramurza and Haryadi (2016) which states that Audit Quality has no effect on Firm Value. Selection of audit services at Big 4 KAP cannot affect the growth of firm value. This can be due to the fact that not everyone who will buy shares in a company always considers the results of the auditing (audit opinion) so that it will not affect the increase in company value. The second reason is that most Indonesians are more concerned with how much profit they will get from the capital invested in the company later. Some of these cases can strengthen the conclusions of the results of this study, namely audit quality cannot affect the growth 
or increase in firm value. The Influence of the Board of Directors, Independent Commissioners, Managerial Ownership, Institutional Ownership, Audit Committee and Audit Quality on Company Value The independent variable, namely the good corporate governance mechanism proxied by the board of directors, independent commissioners, managerial ownership, institutional ownership, audit committee, and audit quality do not have a simultaneous (joint) significant effect on firm value.

This is because the independent variables, namely the board of directors, independent commissioners, managerial ownership, institutional ownership, audit committee and audit quality only have a small percentage of $3 \%$ to explain the company's value as proxied by Tobin's Q. While the remaining $97 \%$ is explained by other variables not examined in this study. All of these variables cannot be a trigger in increasing firm value, because most of these variables do not have a positive impact on increasing firm value or have absolutely nothing to do with the growth process of firm value. Therefore, if combined together the variables of the board of directors, independent commissioners, managerial ownership, institutional ownership, audit committee and audit quality will still not affect the growth of firm value.

\section{CONCLUSIONS}

Based on the research results, the following conclusions can be drawn:

1. The good corporate governance mechanism proxied by the Board of Directors has no effect on the Value of Banking Companies on the IDX for the 2015-2018 period.

2. The good corporate governance mechanism proxied by the Independent Commissioner has no effect on the Value of Banking Companies on the IDX for the 2015-2018 period.

3. The good corporate governance mechanism which is proxied by Managerial Ownership has no effect on the Value of Banking Firms on the IDX for the 20152018 period.

4. Good corporate governance mechanisms that are proxied by Institutional Ownership have a positive effect on the Value of Banking Companies on the IDX for the 2015-2018 period.

5. The good corporate governance mechanism proxied by the Audit Committee has no effect on the Value of Banking Companies on the IDX for the 2015-2018 period.

6. Good corporate governance mechanism proxied by Audit Quality has no effect on the Value of
Banking Companies on the IDX for the 2015-2018 period.

7. The good corporate governance mechanism proxied by the Board of Directors, Independent Commissioners, Managerial Ownership, Institutional Ownership, the Audit Committee and Audit Quality do not simultaneously (jointly) affect the Value of Banking Companies on the IDX for the 2015-2018 period.

\section{REFERENCES}

[1] R. N. K. Supriadi, "Supriadi, R. N. K. (2014). Pengaruh keputusan investasi, keputusan pendanaan dan kebijakan deviden terhadap nilai perusahaan," Universitas Widyatama, 2014.

[2] D. Tjondro and R. Wilopo, "Pengaruh Good Corporate Governance (Gcg) Terhadap Profitabilitas Dan Kinerja Saham Perusahaan Perbankan Yang Tercatat Di Bursa Efek Indonesia," J. Bus. Bank., vol. 1, no. $1, \quad$ p. $1, \quad 2011$, doi: 10.14414/jbb.v1i1.148.

[3] M. B. Lozano, B. Martínez, and J. Pindado, "Corporate governance, ownership and firm value: Drivers of ownership as a good corporate governance mechanism," Int. Bus. Rev., vol. 25, no. 6, pp. 1333-1343, Dec. 2016, doi: 10.1016/j.ibusrev.2016.04.005.

[4] E. Empírica, "Profitability and Social Performance of Microfinance Institutions: Empirical Evidence of Relations Between Different Types of Variables.," Rev. Econ. Mund., vol. 27, pp. 189-214, 2011.

[5] D. I. Widyastuti, "Pengaruh Kepemilikan Manajerial, Kepemilikan Institusional, dan Proporsi Dewan Komisaris Independen terhadap Manajemen Laba," JEBDEER J. Entrep. Bus. Dev. Econ. Educ. Res., vol. 1, no. 2, pp. 1-8, 2018, doi: 10.32616/jbr.v1i2.64.

[6] M. A. Ujiyantho and B. Agus Pramuka, "Mekanisme Corporate Governance, Manajemen Laba dan Kinerja Keuangan (studi pada perusahaan go publik sektor manufaktur)," Simp. Nas. Akunt. X, no. Juli, pp. 1-26, 2007.

[7] L. Christiani and V. Herawaty, "Pengaruh Kepemilikan Manajerial, Komite Audit, 
Leverage, Profitabilitas, Dan Ukuran Perusahaan Terhadap Nilai Perusahaan Dengan Manajemen Laba Sebagai Variabel Moderasi," Pros. Semin. Nas. Cendekiawan, p. 2, 2019, doi: 10.25105/semnas.v0i0.5824.

[8] N. A. Wahab, L. F. A. Hassan, S. A. M. Shahid, and S. N. Maon, "The Relationship Between Marketing Mix And Customer Loyalty In Hijab Industry: The Mediating Effect Of Customer Satisfaction," Procedia Econ. Financ., vol. 37, no. 16, pp. 366-371, 2016, doi: 10.1016/s2212-5671(16)30138-1.

[9] Catharine and dr. H. Ismail, "Pengaruh Mekanisme Good Corporate Governance Terhadap Kinerja Keuangan Perusahaan Manufaktur," Skripsi-2018, vol. 19, no. 1, pp. 543-555, 2018.

[10] A. Hadi Khasani and C. Anwar, "Tenure Audit, Reputasi Auditor dan Kualitas Audit pada Perusahaan Manufaktur: Analisis Kompleksitas Operasi sebagai Pemoderasi," J. Ris. Akunt. dan Perpajak. JRAP, vol. 5, no. 1, pp. 1-13, 2018.

[11] J. Heath and W. Norman, "Stakeholder theory, corporate governance and public management: What can the history of staterun enterprises teach us in the post-Enron era?," J. Bus. Ethics, vol. 53, no. 3, pp. 247265, 2004, doi: 10.1023/B:BUSI.0000039418.75103.ed. 